\title{
Determinant of Sharia Bank's Financial Performance during the Covid-19 Pandemic
}

\author{
Reza Nurul Ichsan ${ }^{1}$, Sudirman Suparmin ${ }^{2}$, Mohammad Yusuf ${ }^{3}$, Rifki Ismal ${ }^{4}$, Saleh \\ Sitompul ${ }^{5}$ \\ ${ }^{1}$ Universitas Pembinaan Masyarakat Indonesia \\ ${ }^{2}$ Universitas Islam Negeri Sumatera Utara, Indonesia \\ ${ }^{3}$ Universitas Pembangunan Panca Budi, Indonesia \\ ${ }^{4}$ Departement of Islamic Economic and Finance, Bank Indonesia \\ ${ }^{5}$ STIE ITMI Medan \\ rezaichsan31@gmail.com,sudirman.suparmin@uinsu.ac.id,yusuflangit8@gmail.com, \\ rifki_ismal@yahoo.com,jokowiahmad44@gmail.com
}

\begin{abstract}
Financial performance as a measuring instrument to know the process of implementing financial resources owned by the company. The Covid-19 pandemic has impacted the banking sector, resulting in poor financing due to debtors' disbursements as a result of the large number of people losing their jobs and difficulties in financing payments. This research aims to analyze the financial performance of Islamic Banks during the Covid-19 pandemic, using records of annual financial statements from 2011 to 2020 through Multiple Linear Regression testing and linearity testing of the model used Ramsey test. As a result of this study, the results of the t test found that the Capital Adequacy Ratio (CAR), Operating Costs to Operating Income (BOPO), Financing to Deposit Ratio (FDR) had a positive and significant effect on financial performance (ROA) while Not Performing Financing (NPF) had a negative and insignificant effect on financial performance (ROA). Furthermore, simultaneously capital adequacy ratio (CAR), Operating Costs to Operating Income (BOPO), Financing to Deposit Ratio (FDR) and Not Performing Financing (NPF) significantly influenced the financial performance (ROA) of Sharia banks in Indonesia.
\end{abstract}

Keywords

financial performance; sharia banks, covid-19

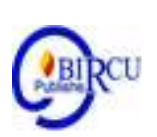

\section{Introduction}

Sharia banking is one of the financial institutions that has the function of balancing, coordinating and coordinating various sectors of the economy. The strategic role in the development is to improve the quality of livelihoods of citizens as a whole through national stability and economic growth. Meanwhile, the bank is "Department of store, which is a body or organization that provides services / services for various financial services where the vital activities are receiving payments, savings, current deposits and deposits, which is used to be able to make credit / money loans aimed at every community needs, and banks are places used in exchanging money.

The banking law No.7 of 1992 was later revised by Law No.10 of 1998 stating that the bank is a business entity in an effort to increase the level of people's livelihoods, raise funds from the community in the form of a deposit and then distributed again to the community with the form of a credit or another. Sharia banks have a definition of a bank that conducts its business activities based on sharia principles, which consists of Sharia Commercial Banks and Sharia People's Financing Banks. Another function owned by the bank, as Financial Intermediary, is an institution that plays a role to be able to bring 
together the user and the owner of the fund. Thus, banking activities must continue to process efficiently and effectively based on macro and micro scales.

So it can be concluded if the bank serves as a financial intermediary and to improve people's livelihoods, to raise funds from the community in the form of a deposit and then distributed again to the community with the form of a financing or other. The functions of the bank are:

1) Namely As Agent of Trust has the meaning of important guidelines of the activities of a bank, namely trust in disbursing and raising funds. The importance of trust from the public who want to deposit funds in the bank and believe if the money it has will not be misused from the bank. The bank needs to manage well the money deposited by the customer, so that the bank does not lose money, and easily the customer's savings can be taken in the future. In this way the public has the willingness to deposit funds in banks. The public is confident that the bank will not misuse their funds. Furthermore, sharia banks are trusted, on the contrary, trusted customers become the basis of the element of trust from the bank towards customers. The Bank carefully believes in placing funds managed in the customer's business, as well as the needs of other customers. The trust owned by the bank is that the loan by the borrower (debtor) is not misused. The loan/financing fund is used properly by the customer, the funds are returned at the maturity date. The most important thing related to this financing is that the customer has the intention to be able to make a refund as well as various other obligations, which have a connection to the loan / financing.

2) Namely as an Agent of Development which means that there must be a link between the real sector and the financial sector in the economic activities of the community. Interaction between the two must continue to influence each other, namely between the financial sector and the real sector, the two are related. Such is the need for a bank activity, namely in collecting and channeling funds to smooth economic activities in the real sector. There is a possibility derived from the activities of this bank, that customers can carry out economic activities that include consumption of goods / services, investment, and distribution, the three economic activities are inseparable from the use of money and the smoothness of this activity, the aim of which is as an activity to support the economic development of a country.

3) namely as an Agent of Service has the meaning of other things that can be done by banks where the main activities are the collection and distribution of funds that can provide a variety of service offers from other banks to the community. There is a connection between the services offered by this community and the economic activities of society in general. Other things offered include money transfer or remittance services, provision of bank guarantees, settlement of bills, and can in deposit valuables.

If reviewed based on aspects of the use of funds in exchange for services to banks, including loans or deposits, banks can be categorized as follows: 1), Conventional Banks which in their operational activities include channeling or collecting funds, giving and giving in return for interest or in return at a percentage based on funds in a period of time. That percentage is determined per year in general. 2), Sharia banks are banks, which in their operational activities include channeling or raising funds to give and provide rewards based on sharia principles, namely profit-share and buying and selling. Sharia banks are "banks that carry out their operational activities, which are based on Islamic/Sharia principles".

Furthermore, according to Islamic law prohibits the existence of usury system because it is burdensome by one party, in accordance with it, the operational activities of Sharia banking based on partnership or profit share on all business activities on the basis of fairness and conformity. Sharia banks are financial institutions whose main business is to 
provide credit and other services in payment traffic and money circulation that operates on islamic sharia principles.

Meanwhile, based on the Decree of the Board of Directors of Bank Indonesia No. 32/34/KEP/DIR 12 May 1999 concerning banks with sharia principles, basically the activities of sharia banks include Mudarabah, Istishna, Kafalah, Ijarah Wa Iqtina, Ijarah, Hiwalah, Qardh, Musyarakah, Ujr, Salam, Al Rahn, Al Qard Ul Hasan, Sharf, Wakalah, And Wadi'ah. In recent years, the growth of Islamic banking has experienced significant developments. For more details, in the table below, exposure to the development of Islamic banking institutions in Indonesia are:

Table 1. Development of Indonesia Sharia Banking Financial Performance The Ratio of the Performance of Sharia Banks in Indonesia

\begin{tabular}{|c|r|r|r|r|r|r|}
\hline UNIT & \multicolumn{1}{|c|}{ TAHUN } & CAR \% & \multicolumn{1}{|c|}{ ROA \% } & NPF \% & \multicolumn{1}{c|}{ BOPO \% } & \multicolumn{1}{c|}{ FDR \% } \\
\hline & 2011 & 16,63 & 1,79 & 2,52 & 78,41 & 88,94 \\
\cline { 2 - 7 } & 2012 & 14,13 & 2,14 & 2,22 & 74,97 & 100,00 \\
\cline { 2 - 7 } & 2013 & 14,42 & 2,00 & 2,62 & 78,21 & 100,32 \\
\cline { 2 - 7 } & 2014 & 16,76 & 0,41 & 3,01 & 80,05 & 86,66 \\
\cline { 2 - 7 } & 2015 & 15,02 & 0,49 & 4,84 & 88,03 & 88,03 \\
\cline { 2 - 7 } & 2016 & 16,63 & 0,63 & 4,42 & 96,22 & 85,99 \\
\cline { 2 - 7 } & 2017 & 17,91 & 0,63 & 4,76 & 94,91 & 79,61 \\
\cline { 2 - 7 } & 2018 & 20,39 & 1,28 & 3,26 & 89,18 & 78,53 \\
\cline { 2 - 7 } & 2019 & 20,59 & 1,73 & 3,23 & 84,85 & 77,91 \\
\cline { 2 - 7 } & 2020 & 20,41 & 1,35 & 3,30 & 86,08 & 86,08 \\
\hline
\end{tabular}

Source: OJK Sharia Banking Statistics Data

In the table above, the development of Sharia banking industry shows that it is increasingly showing excellence in strengthening the stability of the National financial system. Financial institutions in this case banks that have a role that is to implement the achievement of national development goals, with the result is necessary something that must be monitored and fostered effectively, so that banking institutions in Indonesia are able or can have a function with a healthy, reasonable, efficient and able to disburse funds to the public for various productive sectors to achieve national development goals.

According to Indonesian banking rules in Law No. 10 of 1998 article 1 Number 1 which explains if banking is all things that have connections with banks and institutions, business activities and instructions or ways on how a bank conducts business activities. Meanwhile, according to Law No. 10 of 1998 Article 1 Number 2, banks are a business entity in an effort to increase the level of people's livelihoods, raise funds from the community in the form of a deposit and then distributed again to the community in the form of a credit or another.

Furthermore, there are 2 (two) types of banks in Indonesia; First, banks conventionally make interest payments. Second, sharia banks conduct their operations based on business profit share. The emergence of sharia banks among conventional banks has a positive impact on society. Conventional banking performs the principle of usury or interest so that with the existence of Sharia banking, people switch sharia banks. Sharia banks have the aim of introducing Islamic principles to various financial transactions as well as the banking industry and related businesses. 
Financial statements are basically a source of information for investors as one of the basic considerations in making capital market investment decisions and also as a means of management responsibility for the resources entrusted to them (Prayoga and Afrizal 2021) . Financial performance is a measuring instrument to know the process of implementing the company's financial resources. It sees how much management of the company succeeds, and provides benefits to the community. Sharia banking is contained in the Law of the Republic of Indonesia No.21 of 2008 article 5, in which the Financial Services Authority is assigned to supervise and supervise banks. Furthermore, this law has a provision if Sharia banks are required to choose the level of health of banks, which includes the quality of Islamic management, solvency, liquidity, rentability, and capital adequacy as well as other matters related to sharia banking business.

At the moment, the world is in a period of fighting the Coronavirus Desease (Covid19) pandemic which is an infectious disease. As a result of the virus, it causes respiratory diseases such as flu, cough, sore throat, fever and more serious cases of pneumonia. Covid19 was discovered in China's Wuhan City in 2019. On March 2, 2020, President Jokowi confirmed a positive case of Covid-19 in Indonesia. To date, Covid-19 positive cases in Indonesia amount to 45,029 cases, 17,833 recovered, and 2,429 died.

Covid-19 can be transmitted very quickly from human to human, so that the number of positive cases of Covid-19 every day increases. Efforts made by the Indonesian government to stop the spread of Covid-19, by implementing a stay at home policy and health prevention. Prevention by maintaining health such as keeping a distance of at least 2 meters from each other, wearing masks, diligently to wash hands, and spraying disinfectants of each house, which is then followed by a policy of Large-Scale Social Restrictions (PSBB).

Furthermore, this policy of social distancing resulted in the whole community being encouraged to stay at home. Himbauan stay at home has an impact on many sectors, especially the banking sector, resulting in slowing financing growth, increasing problematic financing due to the large number of people losing their jobs. Of course, this non-current financing will have an impact on the financial performance of banks (nonperforming financing / NPF) (Fauzi, 2018). During the Covid-19 pandemic, Bank Syariah implemented a policy of delaying payment of financing for some customers who experienced a decrease in revenues for their businesses. The policy can certainly have an impact on the financial performance of Islamic banking. Referring to the above problem, researchers intend to make the topic into a study on the financial performance of the Islamic banking sector as a result of Covid-19. This research aims to analyze the comparison of financial performance during the Covid-19 pandemic.

\section{Review of Literatures}

\subsection{Return on Asset (ROA)}

Profitability is the company's ability to make a profit in relation to sales, total assets and own capital. Profitability ratios are very important to know by users of financial statements because they inform how much the company's ability to generate profits, the greater the profit ratio shows the better management in managing the company (Sartono in Angelia and Toni (2020).

Return on Asset (ROA) is one form of profitability ratio, by using after various capital costs and total assets owned by banks, it can see the ability of a company to be able to earn profit / profit. Because, return on assets is a measurement tool used in the ability of the company and assess the effectiveness to get profit and profit. 
Meanwhile, Return On Asset (ROA) is the ratio between pre-tax profit to total assets of a bank. Return on Asset (ROA) is the ratio of tax profit to total assets of a bank. Return on Asset (ROA) is the ratio of net profit after tax which can be given also understanding as a measuring instrument to be able to provide an assessment of the level of return on assets owned by a company or banking.

If return on asset (ROA) is positive, it can show if the total assets used in operations have the ability to generate profit for the company. If the Return On Assessment (ROA) is negative, it can show if the total assets used for the company's operations do not provide profit (loss). 13 Measurement of the effectiveness of profitability ratio in the company in obtaining profit / profit through the utilization of total ownership of its assets. The formula for obtaining ROA based on SE BI 13/30/DPNP/16 December 2011 is:

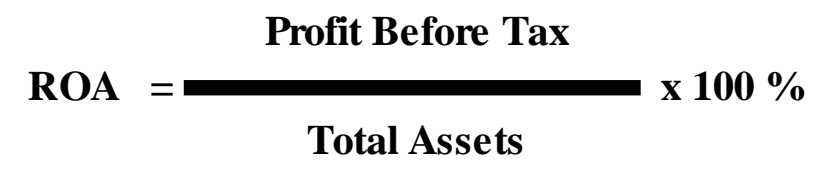

Table 2. Return On Asset (ROA) Assessment Criteria

\begin{tabular}{|c|c|}
\hline Credit Score & Description \\
\hline$>1,22 \%$ & Healthy \\
\hline$>0,98 \%-<1,22 \%$ & Healthy Enough \\
\hline$>0,76 \%-<0,98 \%$ & Unhealthy \\
\hline$<0,76 \%$ & Unhealthy \\
\hline
\end{tabular}

\subsection{Capital Adequacy Ratio (CAR)}

Capital is one of the factors that is vital for banks in developing their businesses, on the other hand has the function of being the main source of financial activities of capital companies, in addition to having a function in supporting various things that can bring losses in the future. Basically the capital owned by the company or bank must be sufficient in the face of all risks of its business activities such as losses to banks or companies. The capital adequacy ratio aims to see certainty to banks to be able to maximize their operations, so as not to suffer losses in the future. If the capital in the banking or the company owned can suffice banking activities then it can facilitate the activities carried out.

CAR is a ratio that shows that all assets from banks have risks such as participation, bills on other banks, credit and securities, as well as given financing derived from their own capital funds, in addition to obtaining various funds sourced from outside the bank. Capital ratio formulated are:

\section{Capital}

CAR = $\times 100 \%$

ATMR 
Table 3. Capital Adequacy Ratio (CAR) Assessment Criteria

\begin{tabular}{|c|c|}
\hline Credit Score & Description \\
\hline$>8 \%$ & Healthy \\
\hline$>6,5 \%-<7,99 \%$ & Healthy Enough \\
\hline$>5,0 \%-<6,49 \%$ & Unhealthy \\
\hline$<4,99 \%$ & Unhealthy \\
\hline
\end{tabular}

\subsection{Not Performing Financing (NPF)}

Not Performing Financing (NPF) is a ratio that can provide a depiction of a bank capable or not to manage problematic financing on the distribution of financing carried out. Non Performing Financing (NPF) is a financial ratio that shows the financing risk obtained by banks caused by the investment/financing of bank funds in different portfolios. It can be said that if the lower the NPF, the lower the risk of financing borne by the bank. Similarly, if the bank has a high NPF, it shows that the bank cannot be professional in managing funds.15 To obtain the value of NPF, the formula can be used, namely:

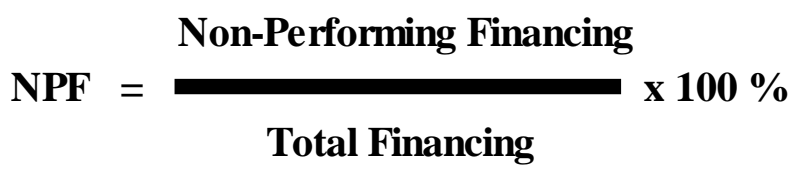

Table 4. Not Performing Financing (NPF) Assessment Criteria

\begin{tabular}{|c|c|}
\hline Credit Score & Description \\
\hline $0.00 \%-<10,35 \%$ & Healthy \\
\hline $10,36 \%-<12,60 \%$ & Healthy Enough \\
\hline $12,61 \%-<14,85 \%$ & Unhealthy \\
\hline$>14,85 \%$ & Unhealthy \\
\hline
\end{tabular}

\subsection{Operating Expenses to Operating Income (BOPO)}

Efficiency ratio is the ratio used to determine the level of ability of a bank in carrying out its corporate activities efficiently. Efficiency ratio is used the term BOPO, to measure the level of ability in terms of management to be able to control the operational funds of banks. When operational funds increase, the costs incurred have the impact of a lack of pre-tax profits and at the end there can be a decrease in the bank's profits. To get the BOPO value, the formula can be used, namely:

Total Operating Expenses

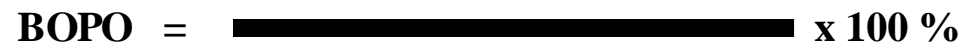

\section{Total Operating Income}

Table 5. Operational Cost Assessment Criteria for Operating Income (BOPO)

\begin{tabular}{|c|c|}
\hline Credit Score & Description \\
\hline$<93,52 \%$ & Healthy \\
\hline $93,52 \%-94,73 \%$ & Healthy Enough \\
\hline $94,73 \%-95,92 \%$ & Unhealthy \\
\hline$>95,92 \%$ & Unhealthy \\
\hline
\end{tabular}




\subsection{Financing to Deposit Ratio (FDR)}

Sharia banking is not known as loan but financing (Syafi'i Antonio, 2001:170). In general, the same concept is shown in Sharia banks in measuring liquidity by using financing to deposit ratio (Muhamad, 2005).

According to Lukman Dendawijaya (2009:116), the Financing To Deposit Ratio (FDR) is: "... a measure of how far banks can afford to refinance depositors' withdrawals by relying on the financing provided as a source of liquidity". Whereas according to Martono (2002:82), financing to deposit ratio is: "... ratio to know the bank's ability to repay obligations to customers who have invested funds with the credits that have been given to its debtors."

Muhammad (2005:266) stated that: Financing in the Islamic banking industry is the distribution of funds to third parties, not banks, and not Bank Indonesia by using several types of contracts. Third party funds in Sharia banks are:

1) Deposit (wadiah) deposits that are guaranteed security and returns but without obtaining any benefit or profit.

2) Participation of capital sharing the proceeds of various risks for general investment.

3) Special investments where the bank only applies as an investment manager to obtain the feedan investors fully take risks on the investment.

FDR can be calculated by using a formula:

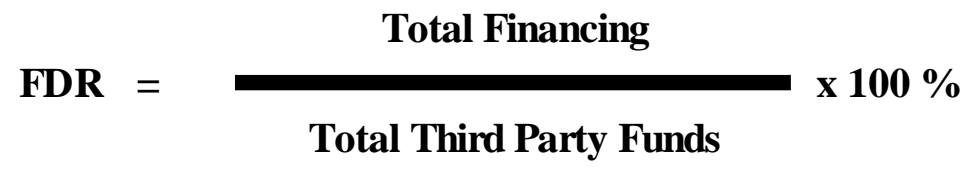

Financing to Deposit Ratio (FDR) is the ratio between the financing provided and the total funds of third parties. FDR measures the ability of Sharia banks to meet all their short-term obligations at maturity. Sharia banks are said to be liquid if they are able to refund depositors at the time of charge and are able to meet financing needs to external parties. So, if the high FDR indicates that the company belongs to the liquid category (Muhammad, 2005: 359).

\subsection{Conceptual Framework}

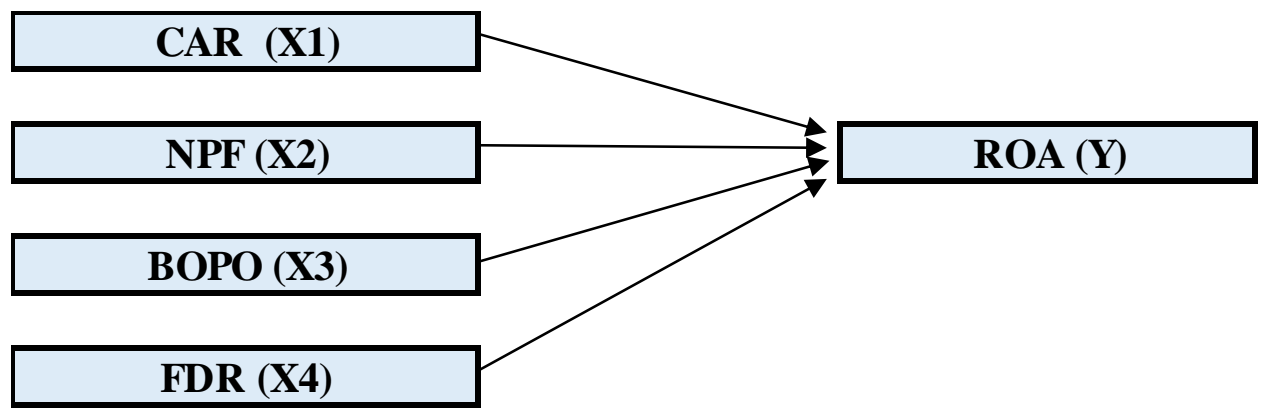




\section{Research Methods}

The research that is diguanakan in this research is quantitative research approach. According to Sugiyono (2019), quantitative research is a research method based on the philosophy of positivism, used to examine certain populations or samples, data collection using research instruments, data analysis is quantitative / statistical, with the aim to test the hypothesis that has been determined. In this research, quantitative data used is in the form of figures published through the official website of every Sharia Commercial Bank registered with the Financial Services Authority (OJK) through www.ojk.go.id.

In this research, the types and data sources used are quantitative data and secondary data, namely data in the form of figures obtained from observation data on financial ratios from financial statements collected from several stages of time and data collected from those registered with the OJK in the period 2011-2020.

This research uses multiple linear regression analysis method. This multiple linear regression analysis is used to test the effect of financial ratios on profit growth.

a. Classic Assumption Test

Ghozali (2009:107) test classic assumptions used to test, whether the regression model used in this study is worth testing or not. Classic assumption tests in this study included tests of normality, multicoloniality, heterosexastiity, and autocorrelation.

b. Test the Goodness Of Fit

1) $\mathrm{T}$ test (Hypothesis Test) Used to determine the significant influence of each independent variable in the form of CAR, NPF, BOPO, and FDR on ROA dependent variables individually.

2) Statistical Test $F$ Used to determine the significant influence between three independent variables CAR, NPF, BOPO, and FDR on ROA dependent variables together.

\section{Results and Discussion}

This study examined the influence of CAR, NPF, BOPO, and FDR ratios on banking financial performance (ROA) in the period 2011-2020.

\subsection{Multiple Linear Regression Interpretation}

By estimating the determinant data of Bank Syariah Indonesia's financial performance, the following data are presented in table 3 below. So that the research analysis model as follows:

\section{$\mathrm{Y}=\mathbf{8 , 9 8 0}+\mathbf{1 , 9 8 0} \mathrm{X} 1-1,830 \mathrm{X} 2-\mathbf{9 , 7 4 0} \mathrm{X3}$}

Where Y/ Financing agreement $=8980, \mathrm{X} 1 /$ Murabahah Financing $=1,980, \mathrm{X} 2 \mathrm{/}$ Financing mudhabarah $=-1,830, \mathrm{X} 3 /$ Financing Musyarkah $=-9740$ 
Table 6. Regression Estimation Results

\begin{tabular}{|c|c|c|c|c|}
\hline $\begin{array}{l}\text { Dependent Variable: } \\
\text { Method: Least Squar } \\
\text { Date: } 01 / 10 / 21 \text { Tim } \\
\text { Sample: } 20112020 \\
\text { Included observation }\end{array}$ & $\begin{array}{l} \\
\text { S } \\
19: 55\end{array}$ & & & \\
\hline Variable & Coefficient & Std. Error & t-Statistic & Prob. \\
\hline $\mathrm{C}$ & -4.810 .130 & 8.482 .598 & -0.567059 & 4,1333 \\
\hline $\mathrm{X} 1 / \mathrm{CAR}$ & 0.117677 & 0.170463 & 0.690337 & 3,6159 \\
\hline $\mathrm{X} 2 / \mathrm{NPF}$ & -0.469356 & 0.504236 & -0.930826 & 2,7409 \\
\hline $\mathrm{X} 3 / \mathrm{BOPO}$ & 0.013773 & 0.063838 & 0.215757 & 5,8173 \\
\hline $\mathrm{X} 4 / \mathrm{FDR}$ & 0.051078 & 0.056603 & 0.902392 & 2,8347 \\
\hline R-squared & 0.979283 & Mean dependent var & & 9.246 .000 \\
\hline Adjusted R-squared & 0.979323 & S.D. dependent var & & 6.628 .591 \\
\hline S.E. of regression & 4.969 .506 & Akaike info criterion & & 1.095 .654 \\
\hline Sum squared resid & 12347.99 & Schwarz criterion & & 1.110 .783 \\
\hline Log likelihood & -4.978 .270 & Hannan-Quinn criter & & 1.079 .057 \\
\hline F-statistic & 2.753 .120 & Durbin-Watson stat & & 2.454 .458 \\
\hline Prob(F-statistic) & 0.148165 & & & \\
\hline
\end{tabular}

Sumber : Data diolah, 2020

Based on the above table and equation model, it can be concluded that Capital Adequacy Ratio (CAR) or capital of 0.117 means that if the financial performance (ROA) rises by 1 percent will increase the Capital Adequacy Ratio (CAR) by 0.117. Not Performing Financing (NPF) of -0.469 means that if Not Performing Financing (NPF) rises by 1 percent it will improve financial performance (ROA) by -0.469 . Operating Expenses to Operating Income (BOPO) of 0.013 means that if operating expenses to operating income (BOPO) increase by 1 percent, it will improve financial performance (ROA) by 0.013. Financing to Deposit Ratio (FDR) of 0.051 means that if the Financing to Deposit Ratio (FDR) rises by 1 percent it will improve financial performance (ROA) by 0.051 .

Coefficient of determination (R2) measures how far the model's ability to explain dependent variable vaiation (Ghozali, 2005) R2 value or determination coefficient of 0.979 indicates that variations of capital adequacy ratio (CAR), Not Performing Financing (0.979) indicate that variations of capital adequacy ratio (CAR), Not Performing Financing (0.979) NPF), Operating Costs to Operating Income (BOPO), Financing to Deposit Ratio (FDR) were able to explain financial performance (ROA) of $97.9 \%$ while the remaining $02.1 \%$ variation of financial performance (ROA) was explained by other variables that were not included in the model or not researched. Interpretation of coefficient of determination can also be explained by the adjusted value of $\mathrm{R}$-square which produces more efficient value because it is able to explain the variation of errors of load variables that amount to more than one. 


\subsection{Normality Test}

To find out if it is normal and whether or not the disruptive factor, with the J-B Test. The criteria to know the noramal or not of the pengangggu factor are as follows:

1) If the calculated JB value $\left(=X^{2 \text { calculated }}\right)>X^{\text {2tabel }}$ value, then the hypothesis that the residual, $\mu \mathrm{t}$ there is normal distribution is rejected.

2) If the calculated JB value $\left(=X^{\text {2calculated }}\right)<X^{\text {2tabel }}$ value, then the hypothesis that the residual, $\mu \mathrm{t}$ there is normal distribution cannot be rejected.

Table 7. Normality Test JB Test

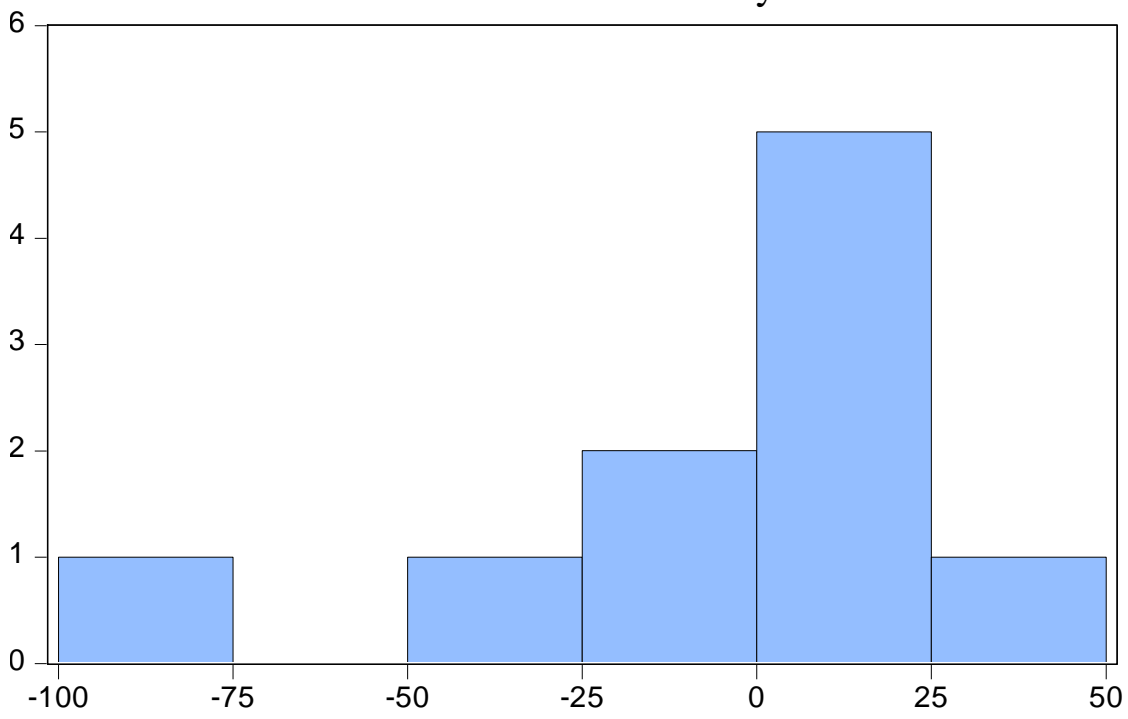

Series: Residuals

Sample 20112020

Observations 10

Mean

$-2.34 \mathrm{e}-14$

Median

12.37194

Maximum

48.49842

Minimum $\quad-86.83951$

Std. Dev. $\quad 37.04051$

Skewness $\quad-1.239877$

Kurtosis $\quad 4.164635$

Jarque-Bera $\quad 3.127316$

Probability

Sumber : Data diolah, 2020

Based on the estimated J-B test in the table above, obtained the amount of JarqueBera value at probability of $0.209>0.05$, it can be concluded that the data distributed normally. This means that the empirical model used in the model has residual or normal distributed disruptive factors that cannot be rejected.

\subsection{Linearity Test}

In multiple linear regressions, the linearity of the model is a mustc assumption. Linearity tests are used to test whether the linear specifications in the model are acceptable. In this study to test the linearity of the model used Ramsey test.

Table 8. Linearity Test - Ramsey Reset Test

\begin{tabular}{|c|c|c|c|}
\hline \multicolumn{4}{|c|}{$\begin{array}{l}\text { Ramsey RESET Test } \\
\text { Equation: UNTITLED } \\
\text { Specification: Y C X1 X2 X3 X4 } \\
\text { Omitted Variables: Squares of fitted values }\end{array}$} \\
\hline (n) & Value & df & Probability \\
\hline $\begin{array}{c}\text { t-statistic } \\
\text { F-statistic } \\
\text { Likelihood ratio }\end{array}$ & $\begin{array}{l}1.615 .355 \\
2.609 .371 \\
5.021 .941\end{array}$ & $\begin{array}{c}4 \\
(1,4) \\
1\end{array}$ & $\begin{array}{l}0.1815 \\
0.1815 \\
0.0250\end{array}$ \\
\hline
\end{tabular}


Table 8 shows that the probability of $\mathrm{F}$ calculates $0.181>0.05$, so that linearity is met. The actual linearity test is not absolute haarus used, where if the theories of the relationship between free variables and bound variables are already strong then linearity tests are not absolutely used. But to reinforce the assumption argument it provides a way of testing linearity.

\subsection{Auto-co-oration Test}

Autocoration is obtained by definition as a correlation between members of a series of observations sorted by time. In the time series data, observations are sorted chronologically, so the probability of autocorrelation between observations or observations is very large, especially when the observation time is very short,

To test the autocorrelation in this model is used Lagrage Test multiplier Tset (LM Test), namely by comparing the statistical X2 value (calculate with X2 value table with criteria keputuasn as follows:

1) If the value of $X 2$ calculates the $<X 2$ table then the zero hypothesis (Ho) says it cannot be rejected, meaning there is no autocorrelation.

2) If the $X 2$ value calculates the $>X 2$ table then the zero hypothesis (Ho) says it is rejected, meaning there is autocorrelation.

Table 9. Autocoration Test - Serial Correlation LM Test

\begin{tabular}{|l|c|l|c|}
\hline Breusch-Godfrey Serial Correlation LM Test: \\
\hline F-statistic & 2.865 .878 & Prob. F(2,3) & 1,3986 \\
\hline Obs*R-squared & 6.564 .265 & Prob. Chi-Square(2) & $\mathbf{0 , 2 6 0 4}$ \\
\hline & & \\
Test Equation: \\
Dependent Variable: RESID \\
Method: Least Squares \\
Date: 01/10/21 Time: 19:59 \\
Sample: 2011 2020 \\
Included observations: 10 \\
Presample missing value lagged residuals set to zero.
\end{tabular}

Sumber : Data diolah, 2020

Based on the estimated results that the LM Test is known Obs $\mathrm{R}^{*}$-squared value of $0.2604>0.05$, meaning that ho hypothesis can not be rejected so it can be concluded that empirical model has met the criteria of no autocorrelation. Autocorrelation test can also be done by dw test (Durbin Watson Test).

\section{Conclusion}

Based on the results of the $t$ test it is known that the Capital Adequacy Ratio (CAR), Operating Costs to Operating Income (BOPO), Financing to Deposit Ratio (FDR) have a positive and significant effect on financial performance (ROA) while Not Performing Financing (NPF) has a negative and insignificant effect on financial performance (ROA)

Simultaneously the Capital Adequacy Ratio (CAR), Operating Costs to Operating Income (BOPO), Financing to Deposit Ratio (FDR) and Not Performing Financing (NPF) significantly impacted the financial performance (ROA) of Sharia banks in Indonesia. 
In an effort to improve the financial performance of Sharia banking, the potential should be able to support sharia banking performance, such as returns that provide convenience for customers, OJK regulations that support Sharia Banks and are committed to improving MSME business to the maximum by providing financing with easy terms.

\section{References}

Angelia, N., and Toni, N. (2020). The Analysis of Factors Affecting Dividend Policy in Food and Beverage Sector Manufacturing Companies Listed in Indonesia Stock Exchange in 2015-2017. Budapest International Research and Critics InstituteJournal (BIRCI-Journal). P. 902-910.

Antonio, muhammad Syafi'i. 2001. Bank Syariah Dari Teori ke Praktik. Gema Insani Press.Jakarta.

Bank Indonesia, 1992. Undang-Undang Nomor 7 Tahun 1992 tentang Perbankan.(Sebagaimana telah diubah dengan Undang-Undang Nomor 10 Tahun 1998). http://www.bi.go.id/id/tentang-bi/uu-bi/Documents/uu_bi_1099.pdf

Bank Indonesia, 1998. Undang-Undang Nomor 10 Tahun 1998 tentang Perbankan,(Direktur Direktorat Hukum Bank Indonesia, 65). https://doi.org/10.1007/s13398-014-0173-7.2

Dendawijaya, Lukman. 2009. Manajemen Perbankan. Jakarta: Ghalia Indonesia.

Fauzi, Gustani. "Kinerja dan Langkah Straegis Pengembangan Perbankan Syariah di Indonesia, Volume 2, No. 1.

Ghozali, Imam. 2009. "Aplikasi Analisis Multivariate dengan Program SPSS“.Semarang : UNDIP.

Gujarati, Damodar N, (2004).Basic Econometrics, Fourth edition, Singapore. McGraw-Hill Inc.

Martono. (2002). Bank dan Lembaga Keuangan Lain. Ekonisia. Yogyakarta

Muhammad. 2005. Manajemen Bank Syariah. Yogyakarta: UPP AMPYKPN.

Prayoga I., and Afrizal, T. (2021). Perceptions of Educators, Accounting Students and Accountants Public Accountant against Ethics of Financial Statement Preparation (Studies at University and KAP in Semarang). Budapest International Research and Critics Institute-Journal (BIRCI-Journal). P. 89-101.

Sugiyono. (2017). Metode Penelitian Kuantitatif, Kualitatif, R\& D.Bandung: CV Alfabeta.

Surat Keputusan Direksi bank Indonesia Nomor 32/34/ KEP/DIR/tanggal 12 Mei 1999 Tentang Bank Umum Berdasarkan Prinsip Syariah. 